DOI 10.22460/infinity.v7i1.p35-44

\title{
THE CORRELATION BETWEEN COGNITIVE STYLE AND STUDENTS' LEARNING ACHIEVEMENT ON GEOMETRY SUBJECT
}

\author{
Udiyono $^{1}$, Muhammad Ridlo Yuwono ${ }^{2}$ \\ ${ }^{1,2}$ Universitas Widya Dharma, Jl. Ki Hajar Dewantara, Klaten 57438, Central Java, Indonesia \\ ${ }^{1}$ udiyono@ unwidha.ac.id, ${ }^{2}$ ridloyuwono90@gmail.com
}

Received: September 25, 2017 ; Accepted: January 27, 2018

\begin{abstract}
The objective of the research is to identify whether there is a positive correlation between cognitive style and students' learning achievement on geometry subject. The research is classified as correlational quantitative research. The population of the research is all students of mathematics education program at Widya Dharma University in the academic year of 2015/2016. The sample is the students in semester IV B. It was taken by cluster random sampling. The instrument is a psychiatric test, GEFT and learning achievement test. The technique of data analysis is simple linear regression analysis. The result of the research is there is a positive correlation between cognitive style and students' learning achievement on geometry subject. The coefficient determination is $\mathrm{r} 2=0.6209$. It means the increase and decrease of students' learning result on geometry subject $62.09 \%$ can be explained by cognitive style with linear correlation equation $\hat{Y}=-2.9650+4.6513 X$. Meanwhile, $37.91 \%$ is influenced by another factor. 13 out of 17 samples are categorized as students FD and 4 students are classified as FI. The mean score of students FD is 16 while students FI is 59.5385. It means students FI has better learning achievement than students FD on geometry subject.
\end{abstract}

Keywords: Cognitive Style, Geometry, Learning Achievement.

\section{Abstrak}

Penelitian ini bertujuan untuk mengetahui apakah terdapat pengaruh yang positif gaya kognitif terhadap hasil belajar mahasiswa pada mata kuliah geometri. Metode yang digunakan adalah metode kuantitatif dengan pendekatan korelasional. Populasi pada penelitian ini adalah seluruh mahasiswa Program Studi Pendidikan Matematika Universitas Widya Dharma Tahun Akademik 2015/2016. Sampel penelitian ini adalah mahasiswa Program Studi Pendidikan Matematika Universitas Widya Dharma semester IV B dengan menggunakan teknik sampling cluster random sampling. Instrumen yang digunakan berupa tes psikiatrik GEFT dan tes hasil belajar. Analisis data yang digunakan pada penelitian ini adalah analisis regresi linear sederhana. Hasil penelitian ini adalah terdapat pengaruh positif gaya kognitif terhadap hasil belajar mata kuliah geometri mahasiswa Program Studi Pendidikan Matematika Universitas Widya Dharma Klaten dengan koefisien determinasi diperoleh $r^{2}=0,6209$. Ini berarti bahwa, meningkat atau menurunnya hasil belajar 62,09\% dapat dijelaskan oleh gaya kognitif mahasiswa melalui hubungan linear dengan persamaan $\widehat{Y}=-2,9650+4,6513 \mathrm{X}$. Sedangkan $37,91 \%$ dipengaruhi oleh faktor lain. Dari 17 sampel yang diambil, mahasiswa yang termasuk kategori FD sebanyak 4 orang dan termasuk kategori FI sebanyak 13 orang. Nilai rata-rata THB kategori FD 16 dan kategori FI 59,5385; yang berarti bahwa mahasiswa FI mempunyai hasil belajar yang lebih baik daripada mahasiswa FD.

Kata Kunci: Gaya Kognitif, Geometri, Hasil Belajar.

How to Cite: Udiyono \& Yuwono, M. R. (2018). The Correlation between Cognitive Style and Students' Learning Achievement on Geometry Subject. Infinity, 7 (1), 35-44. doi:10.22460/infinity.v7i1.p35-44 


\section{INTRODUCTION}

Mathematics is one of basic knowledge that should be mastered. This basic knowledge is used to master other knowledge. Since it is categorized as abstract, learning this knowledge needs deep thinking and skill. A teacher should consider students' ability when he/she wants to teach mathematics. The teacher should know students' cognitive development and how to teach learning material based on their cognitive level. According to Piaget, a human at more than 11 years of age is in formal operational level with some main cognitive development characteristics: hypothesis, abstract, deductive and inductive, logic and probability as well (Suprijono, 2009). Students are still having trouble doing the analytic geometry. The results of Noto, Hartono, \& Sundawan show that the ability of representation and mathematical connections of students in the course of analytic geometry (Noto, Hartono, \& Sundawan, 2016).

Although an individual experiences the same process of cognitive development, he/she will not have the same cognitive style. According to Borich and Tombari, cognitive style is the way how an individual process and think about what they are learning. There are two kinds of cognitive style: Field Dependent (FD) and Field Independent (FI) (Razali, Jantan, \& Hashim, 2003).

Generally, students with cognitive style FD are different from those with FI. Students FD tend to depend on their environment perceptions; have difficulty to focus on, find the main idea, and use prominent instruction; hard to give ambiguous information structure; have difficulty in arranging new information and relating it with the previous one; and have difficulty in retrieving information from long-term memory (Altun \& Cakan, 2006). Meanwhile, students FI are able looking at the part of shadow separated from its form; separating relevant thing from irrelevant form; providing separated information structure from the provided one; rearranging information from previous knowledge context; and tending to be more precise in taking part of the memory. Based on the characteristics, students FD has different way from students FI in learning mathematics.

A teacher should consider students' cognitive style while he/she is teaching geometry because they have different characteristics that ask different treatment too during the learning process. The characteristics can be the guidance in arranging lesson plan for appropriate teaching geometry. This should be done because it is indicated that there is a correlation between cognitive style and students' learning achievement on geometry. Appropriate treatment will result maximum progress.

This research is in line with Apriliantis' study about cognitive style. The conclusion of her research is there is a significant positive correlation between cognitive style with students' learning achievement on physics subject in students class X SMA Kotabaru Jambi (Aprilianti, 2014). Moreover, Suryanti's study releases that there is a correlation between cognitive style toward students' learning achievement on accounting subject (Suryanti, 2014). In addition, Ulya in her research, states that there is high level positive correlation between cognitive style and students' ability in solving a problem (Ulya, 2015).

Based on the background of the study, the problem statement of the research is to find out whether there is a correlation between cognitive style and students' learning achievement on geometry subject. The objective of the research is to identify whether there is a correlation between cognitive style toward students' learning achievement on geometry subject. While, 
the benefit of the research are (1) through the research, it would be identified a description about the correlation between cognitive style and students' learning achievement on geometry subject; (2) the teacher would be helped to arrange a lesson plan on geometry subject that take cognitive style into account.

\section{METHOD}

The method that is used in this research is quantitative method with correlation approach. Independent variable $(\mathrm{X})$ of this research is cognitive style while the dependent variable $(\mathrm{Y})$ is students' learning achievement on geometry. The population of the research is all students of mathematics program at Widya Dharma University in the academic year of 2015/2016. The sample of the research is the students of mathematics program in semester IV B Widya Dharma University. It was taken by using cluster random sampling. The instrument that is used to determine students' cognitive style is psychiatry. The test was developed by Witkin, Moore, Goodenough, \& Cox (1977). The name of the test is GEFT. The test had been measured its reliability by the previous researcher. Its reliability score based on Alpha Cornbach is 0.84 . It means the reliability of GEFT is very high (Khodadady \& Tafaghodi, 2013). GEFT is valid because it has been used in the previous researches. The example of GEFT test is shown in Figure 1.
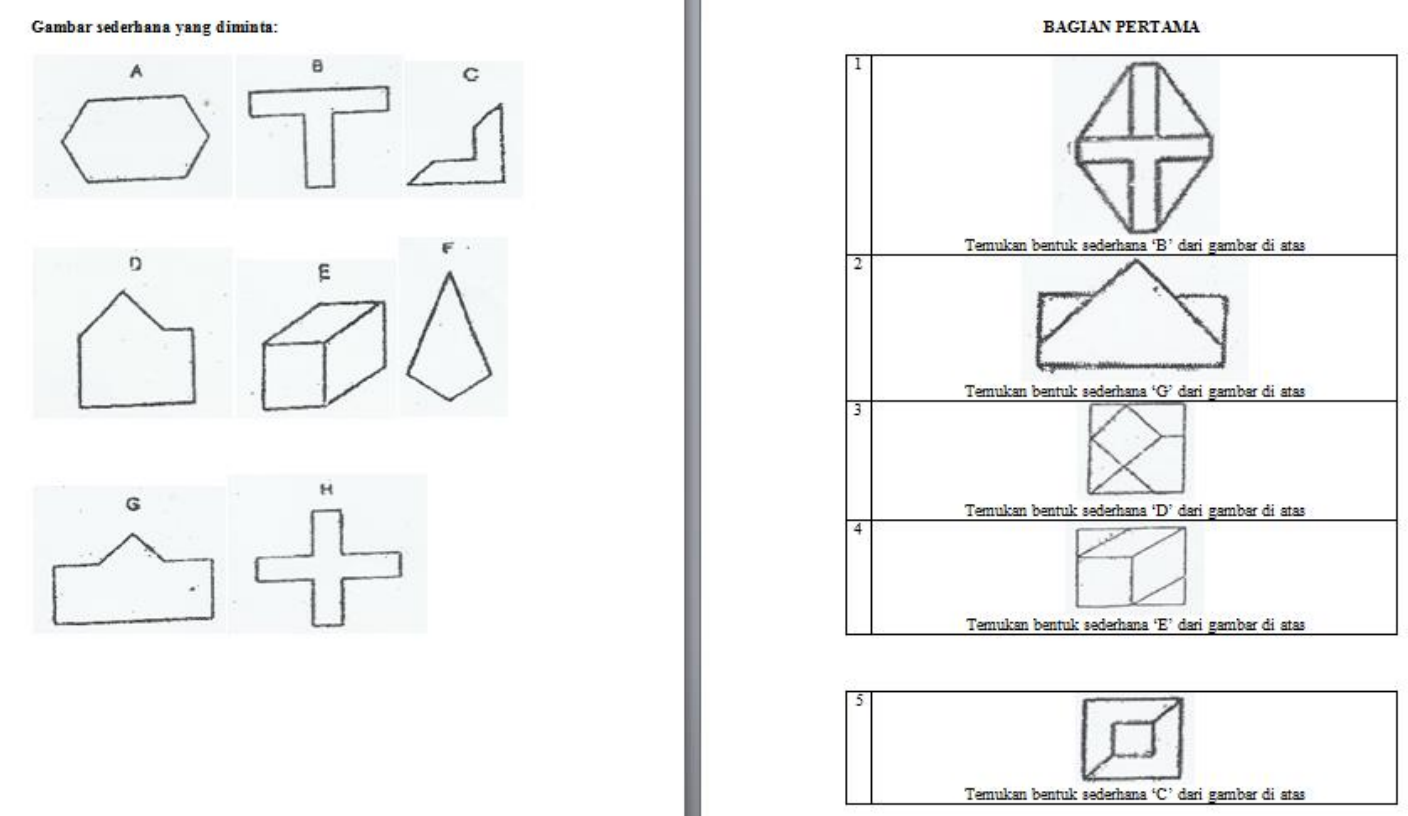

Figure 1. The Example of GEFT Test

Instrument that is used as students' achievement data is taken from students' test. The test instrument had been tried out first before it was used in the research. Tryout was done to know the validity, reliability, discrimination power, and level of difficulty of the question. The contents of the learning achievement test are shown in Figure 2. 


\section{SOAL TES HASIL BELAJAR \\ Mata Kuliah : Geometri \\ SKS : 2 \\ Alokasi Waktu : 40 menit. \\ Sifat Tes : Close Book}

Petunjuk: Kerjakan soal berikut dengan benar dan sistematis!

1. Perhaikangambar berikut! Terdapat berapa pasangan alas dan tinggi jajargenjang KLMN? Sebutkan dan sertai dengan gambamya!

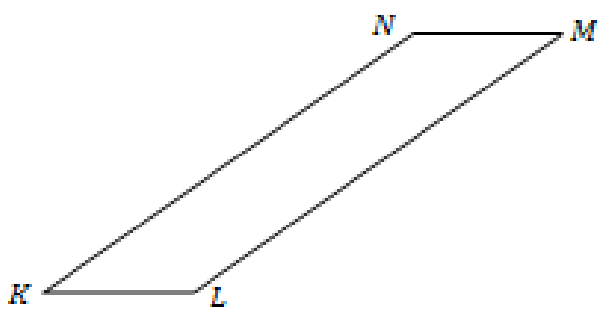

2. Sebuahkarton berukuran tinggi $30 \mathrm{~cm}$ danleb ar $20 \mathrm{~cm}$ Doni menempelkan sebuah foto sehingga sisa karton di sebelahkiri, kanan, atas foto adalah $2 \mathrm{~cm}$. Jika foto dan karton sebangun, tentukan sisa karton di bawah foto!

3. Buktikan bahwa nmus luas daerah segitiga Luas $=\frac{1}{2} \times$ alas $\times$ tinggi dengan menggunakan pendekatan luas daerah jajargenjang!

4. Terdapat dua pendekatan dalam menemukan numus luas daerah jajargenjang. Pendekatan yang pertama dengan menggunakan luas daerah persegipanjang. Pendekatan yangkedua denganmenggunakan luas daerah segitiga. Menurut Anda, pendekatanmanakah yang lebih efektif untuk disampaikan kepada peserta didik SMP? Jelaskan alasan Anda!

Figure 2. The Contents of The Learning Achievement Test

Data analysis that was used in the research is simple linear regression. It includes (1) normality test, (2) regression equation, (3) linearity test, (4) significant regression test, (5) significant coefficient regression test, (6) significant coefficient correlation test, (7) coefficient determination.

\section{RESULTS AND DISCUSSION}

\section{Results}

The result of normality test that used Lilliefors method for the data of cognitive style and students' achievement test on geometrycan be seen in Table 1 as follows.

Table 1. The Result of Normality Test

\begin{tabular}{llccc}
\hline No & \multicolumn{1}{c}{ Variable } & $\mathbf{L}_{\mathbf{o b s}}$ & $\mathbf{L}_{\mathbf{0 . 0 5} ; \mathbf{1 7}}$ & Decision \\
\hline 1 & Cognitive style & 0.1251 & 0.2060 & $\mathrm{H}_{0}$ is accepted \\
2 & Learning achievement & 0.1721 & 0.2060 & $\mathrm{H}_{0}$ is accepted \\
\hline
\end{tabular}


Based on the data in Table 1, the conclusion that can be drawn is cognitive style and students' achievement data come from normal distribution population.

Meanwhile, simple linear regression counting generates regression equation $\hat{Y}=-2.9650+$ $4.6513 \mathrm{X}$. The regression shows that there is an increase for students' learning achievement 4.6513 for every one unit cognitive style increase.

The result of linearity test is shown in Table 2 .

Table 2. Linearity Test Result

\begin{tabular}{lcccccc}
\hline $\begin{array}{c}\text { Sources of } \\
\text { Variance }\end{array}$ & $\begin{array}{c}\text { Sum of } \\
\text { Squares }\end{array}$ & $\begin{array}{c}\text { Degree of } \\
\text { Freedom }\end{array}$ & $\begin{array}{c}\text { Mean } \\
\text { Square }\end{array}$ & $\mathbf{F}_{\text {obs }}$ & $\mathbf{F}_{\mathbf{a}}$ & Decision \\
\hline Regression & 4869.1248 & 1 & & & & \\
Lack of fit & 2117.9046 & 8 & 264.7381 & 2.1687 & 3.7257 & $\mathrm{H}_{0}$ is accepted \\
Pure error & 854.5000 & 7 & 122.0714 & & & \\
Total & 7841.5294 & 16 & & & & \\
\hline
\end{tabular}

Based on the data in table, the conclusion is the correlation between cognitive style and students' learning achievement on geometry is linear.

The result of regression significance test is presented in Table 3.

Table 3.The Result of Regression Significance Test

\begin{tabular}{llcllll}
\hline $\begin{array}{l}\text { Sources of } \\
\text { Variance }\end{array}$ & $\begin{array}{l}\text { Sum of } \\
\text { Squares }\end{array}$ & $\begin{array}{l}\text { Degree of } \\
\text { Freedom }\end{array}$ & $\begin{array}{l}\text { Mean } \\
\text { Square }\end{array}$ & $\mathbf{F}_{\text {obs }}$ & $\mathbf{F}_{\mathbf{a}}$ & Decision \\
\hline Regression & 4869.1248 & 1 & 4869.1248 & 24.5716 & 4.5431 & $\mathrm{H}_{0}$ is rejected \\
Error & 2972.4046 & 15 & 198.1603 & & & \\
Total & 7841.5294 & 16 & & & & \\
\hline
\end{tabular}

Based on the data in table 3 , the conclusion is the correlation between cognitive style and students' learning achievement on geometry is significant.

The result of regression coefficient significance test is $t_{\mathrm{obs}}=4.9570$. Critical area $\mathrm{t}_{0.025} ; 15=$ 2.1314 is $\mathrm{DK}=\{\mathrm{t} \mid \mathrm{t}>1.7531$ or $\mathrm{t}>2.1314\}$. Becauset ${ }_{\mathrm{obs}} \in \mathrm{DK}$, so $\mathrm{H}_{0}$ is rejected. It can be concluded that the regression coefficient is significant.

Based on the correlation coefficient calculation, the value of $r_{x y}=0.7880$. Meanwhile, correlation coefficient significant test is $\mathrm{t}_{\mathrm{obs}}=4.9570$. Critical area $\mathrm{t}_{0.05 ; 15}=1.7531$ is $\mathrm{DK}=\{\mathrm{t} \mid$ $t>1.7531\}$. Becauset $t_{o b s} \in \mathrm{DK}, \mathrm{H}_{0}$ is rejected. Therefore, it can be summarized that there is a positive correlation between cognitive style and students' learning achievement.

Based on the determination coefficient calculation, the value $r^{2}=0.6209$. It means the increase and decrease of students' learning achievement $62.09 \%$ can be explained by cognitive style through linear correlation equation $\hat{Y}=-2.9650+4.6513 \mathrm{X}$. While $37.91 \%$ is influenced by other factor.

Four students out of 17 samples are categorized as students FD and 13 students are classified as students FI. The mean score of students FD is 16.0000 while students FI is 59.5385. It means students FI have better learning achievement than students FD. 


\section{Discussion}

Based on the research data analysis, it can be summarized that there is a positive correlation cognitive style toward students' learning achievement on geometry subject. Based on Altun \& Calkan (2006), the following is the tendency of students FD and FI in general. An individual with FD type tendsto depend on their environment perceptions; have difficulty to focus on, find the main idea, and use prominent instruction; hard to give ambiguous information structure; have difficulty in arranging new information and relating it with the previous one; and have difficulty in retrieving information from long-term memory. Individual with FI type tends to be able looking at the part of shadow separated from its form; separating relevant thing from irrelevant form; providing separated information structure from the provided one; rearranging information from previous knowledge context; and tending to be more precise in taking part of the memory.

The correctness of hypothesis is supported by some related research. Aprilianti's research shows that there is significant positive correlation between cognitive style with students' learning achievement on physics subject (Aprilianti, 2014). Moreover, the result of Suryanti's research is there is correlation between cognitive style toward students' learning achievement on accounting I subject (Suryanti, 2014). In addition, Ulya in her research concluded that there is high level correlation between cognitive style and students' ability to solve problem (Ulya, 2015).

Moreover, this research is accordance with the Sulaiman's research (2013). The research uses naturalistic qualitative approach and takes one student FI and one student FD as the research subject. The method uses worksheet with six activities to gain information about the geometry thought profile of subject research. The activities are (1) drawing rectangles; (2) showing and defining rectangles; (3) selecting rectangles; (4) guessing mysterious figure; (5) identifying the equvalency of two parallelogram definitions; (6) and applying rectangles. The result of the Sulaiman's research (2013) was drawn by analyzing the geometry thought of students that can be identified through six activities. The geometry thought of students FI was identified as follows: they were able to draw 6 different rectangular figures and gave appropriate argument in differenciating them; in showing and defining rectangular figure, they were able to appoint some kinds of rectangular figures like square, rectangle, rhombus, parallelogram, trapezoidal, and kite; they were able to mention the characteristics of the figures and define them; in selecting rectangular figure, the students could guess mysterious figures although they needed some repetitions; in equvalencing two parallelogramdefinitions, the students had not understood about the definition of two equivalent parallelogram so the figures that they appointed were rectangle and parallelogram; in applying rectangular figures, the students were able to find two rectangular figures only and they had not understood the association between them. Meanwhile, the geometry thought of students FD through 6 activities were identified as follows: they were only able to draw 5 different rectangular figures; their argument in differenciating the figures was not appropriate; in showing and defining rectangular figures, they were not able to mention the characteristics and the definition of rectangular figure correctly; in selecting rectangular figures, students did inappropriate selection; students were able to guess mysterious figure but they needed many repetitions; in defining parallelogram, the students did not understand about the definition of parallelogramand they appointed incorrect figure; in applying the rectangular figure, the students just found one rectangular thing and they hadn't found the association between them. 
Analysis of geometry answers from FI and FD students is shown below.

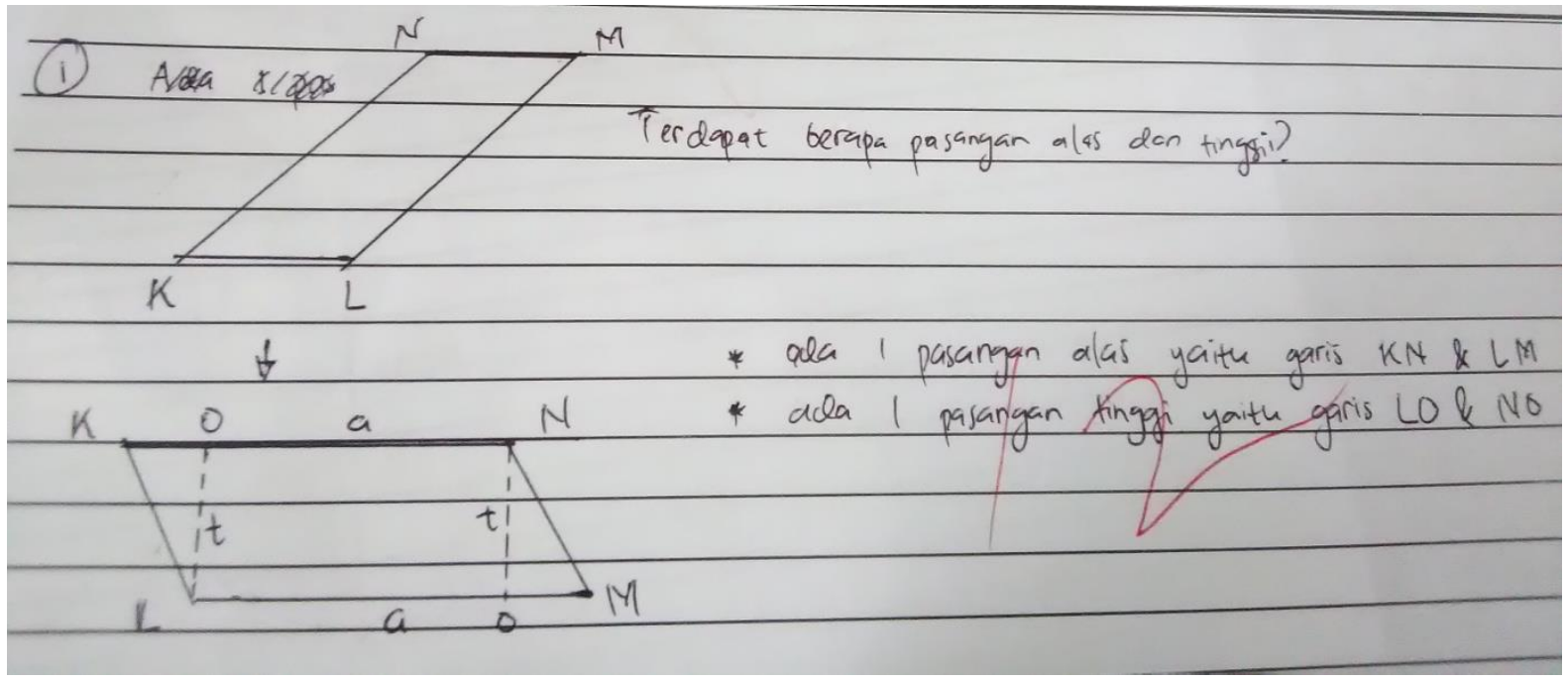

Figure 3. The Answer of Number 1 of Student FI

Based on Figure 3, students FI can name two pairs of base and height. The answer is not perfect, because the parallelogram has eight pairs of base and high.

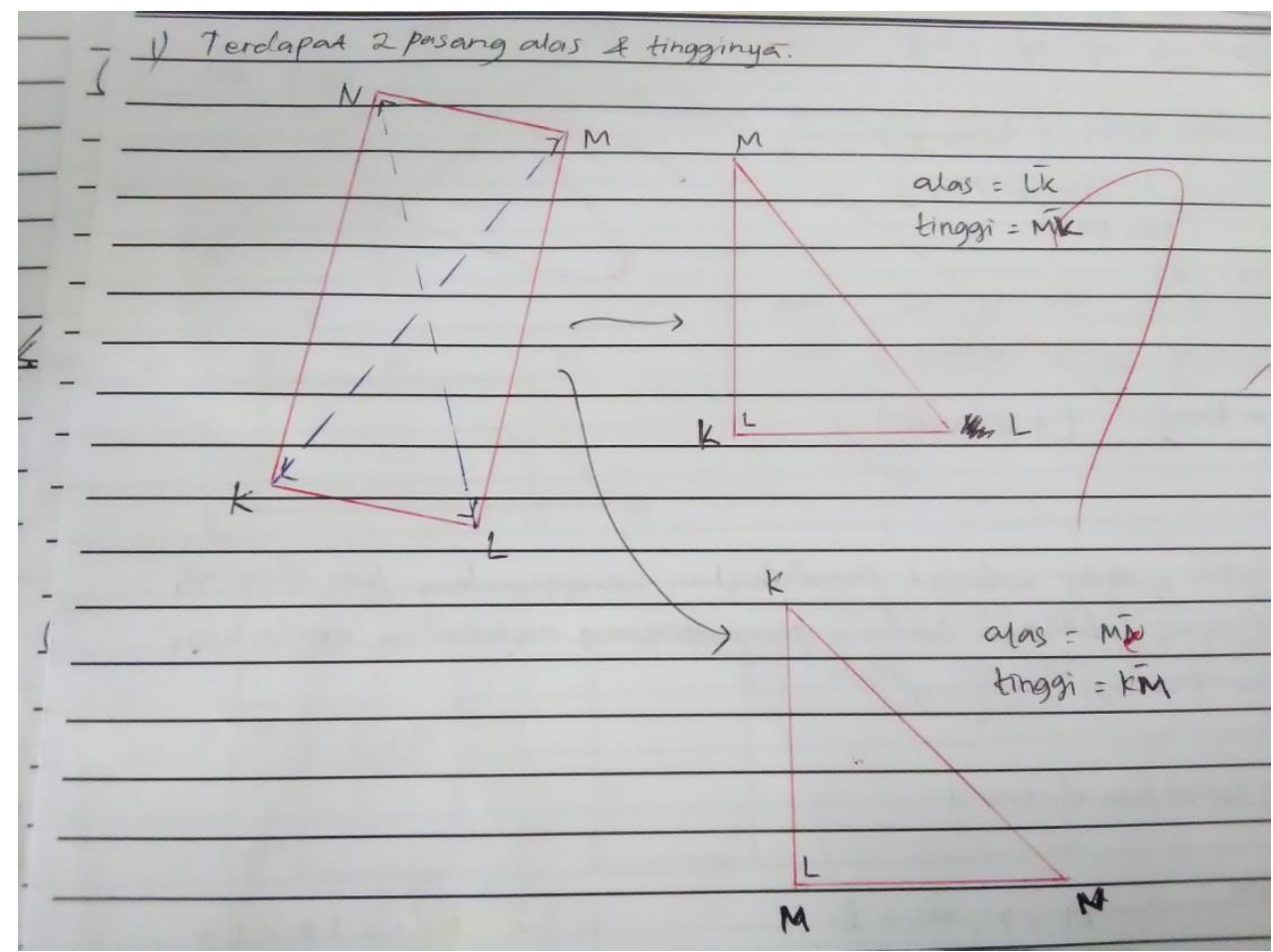

Figure 4. The Answer of Number 1 of Student FD

Based on Figure 4, the students FD actually make the parallelogram to be like a rectangle with its four right angles. Student FD makes two isosceles to determine the base and height of the parallelogram. What this FD student has done is not quite right, because the one asked for about the angle of parallelogram is not right-angled. 


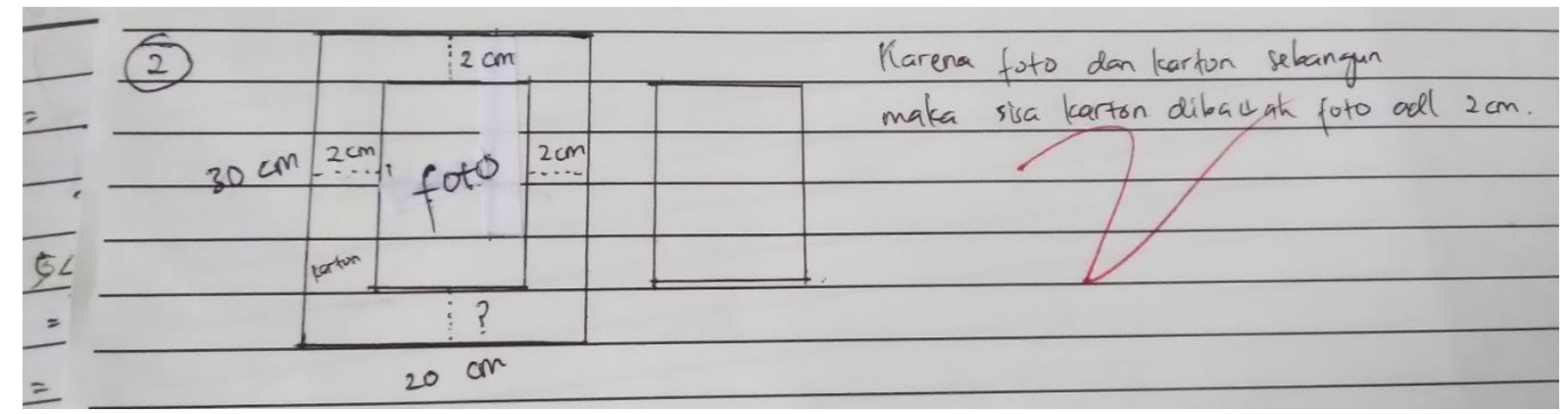

Figure 5. The Answer of Number 2 of Student FI

Based on Figure 5, students FI have drawn the model appropriately. However, the student has not yet made the process of determining the size of the rest of the carton by using the concept of two similar constructions.

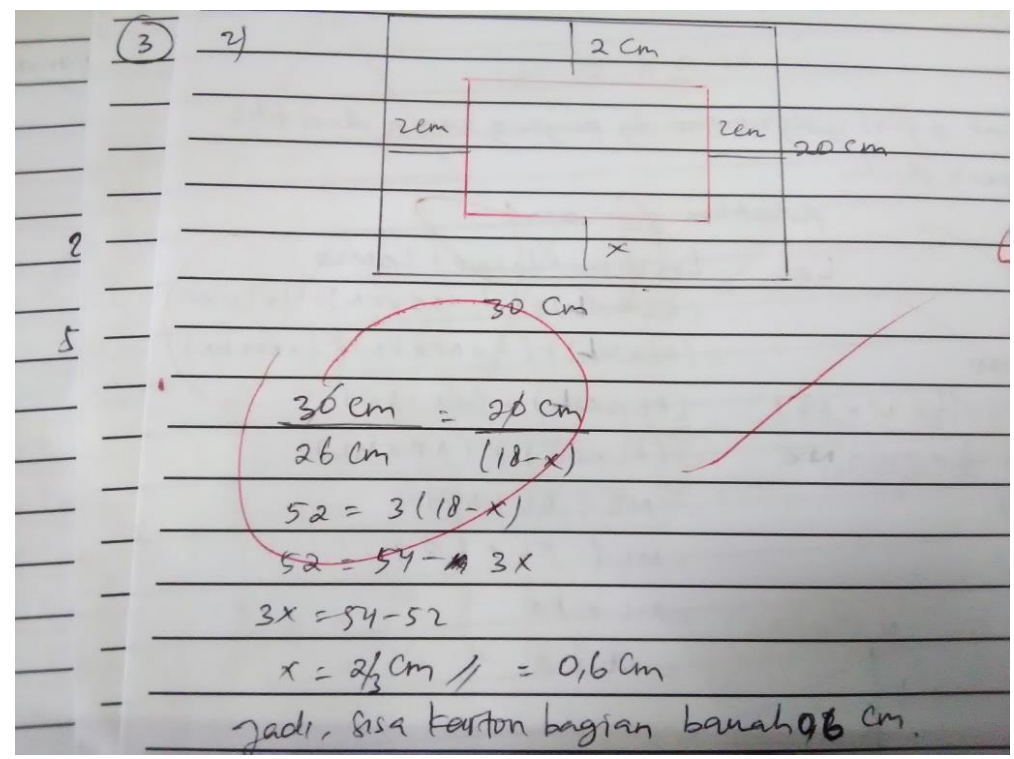

Figure 6. The Answer of Number 2 of Student FD

Based on Figure 6, students FD are wrong in drawing the model. This causes the result of the calculation to be wrong.

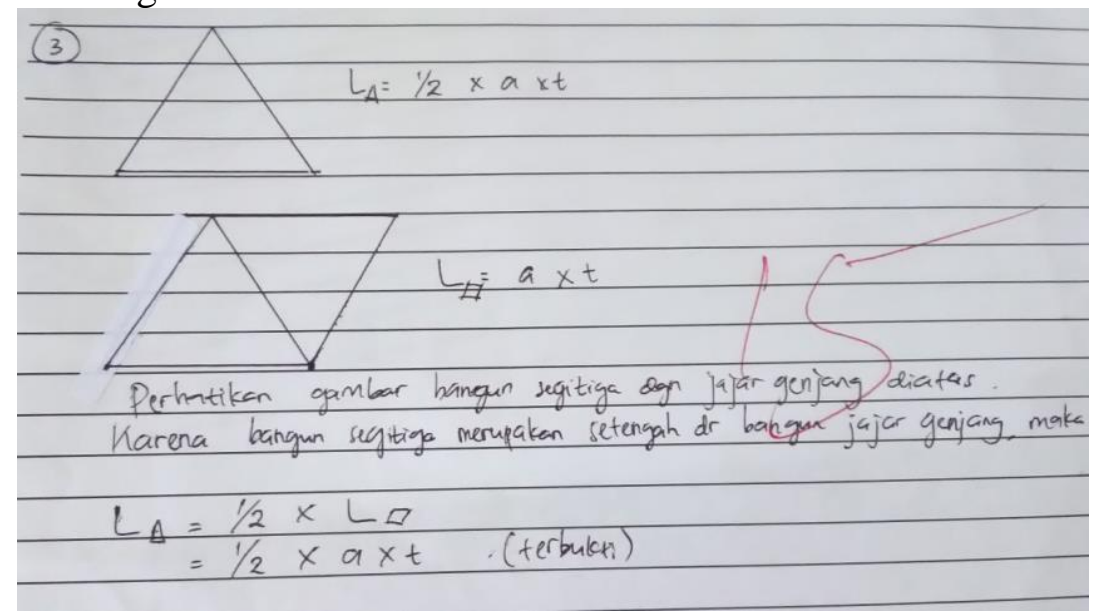

Figure 7. The Answer of Number 3 of Student FI 
Based on Figure 7, students FI prove the formula of the area of the triangle by using a parallelogram image that forms two conjugent triangles. The student immediately stated that the area of the triangle is equal to half of the parallelogram area. However, the student's answers were less systematic. The student does not show the base and height of the image.

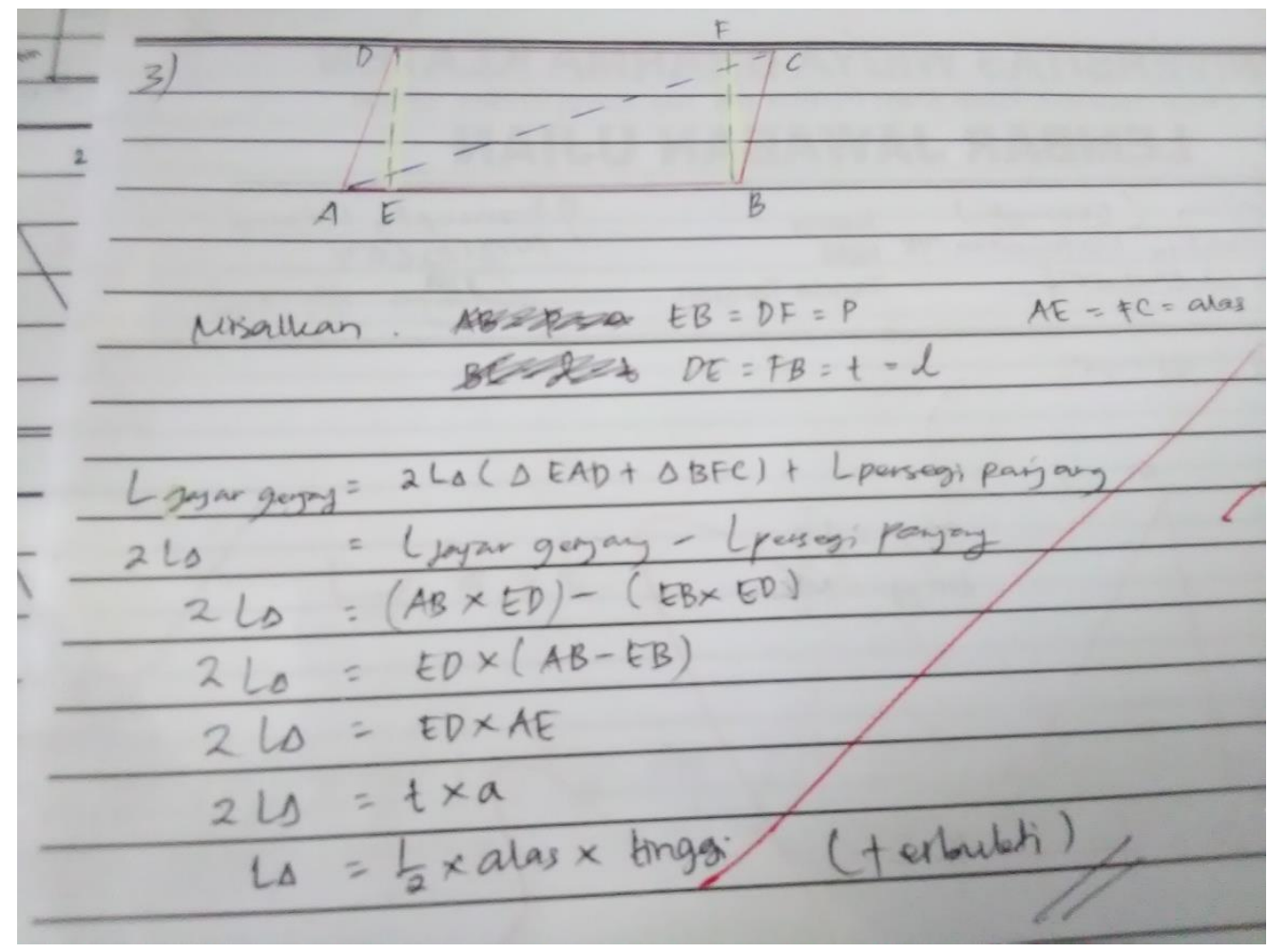

Figure 8. The Answer of Number 3 of Student FD

Based on Figure 8, students FD prove the formula of the area of triangle area by using the resulted image of jejang gejang with rectangle. The results of these intersions form a right triangle. In fact, the triangle that the question maker asks is an arbitrary triangle, not just elbow. Thus, the proof is less precise, because it only applies to right-angled triangles only.

The result of the research supports dimention theory of field dependent and independent by Witkin, Moore, Goodenough, \& Cox (1977) that stated cognitive style approach dimention FI and FD is useful to be implemented in education such as giving description about how students learn, how teachers teach, how students and teachers interact each other, and how students make a decision in choosing job.

Students field independent (FI) and students field dependent (FD) is very different. students FD focus on social environment and depend on external social standard while students FI less focus on social environment and tend to use internal standard use. In the other words, students FD have more interpersonal skill than students FI that tend to be comfortable when they work alone without any interaction with other people.

The characteristics of both cognitive syle dimension can be taken into account when teachers determine learning strategy. When the students are taught using appropriate learning strategy they learn better and the result of learning will increase including in learning geometry subject. 


\section{CONCLUSION}

The conclusion that can be drawn is there is positive correlation between cognitive style toward students' learning achievement on geometry subject for mathematics students at mathematics education program Widya Dharma University. The determination coefficient is $\mathrm{r}^{2}=0.6209$. It means the increase and decrease of students' learning achievement on geometry $62.09 \%$ can be explained by cognitive style through linear correlation formula equation $\hat{Y}=-2.9650+4.6513 X$. The regression obtained showed that the average change in learning outcomes increased by 4.6513 for each increase in cognitive style of students by one unit. While $37.91 \%$ is influenced by other factor.

Teacher especially geometry teacher is suggested to notice students' cognitive style and then take it into accountin arranging effective learning. By considering students' cognitive style, learning achievement can be improved because students experience appropriate learning process based on their characteristics.

\section{REFERENCES}

Altun, A., \& Cakan, M. (2006). Undergraduate students' academic achievement, field dependent/independent cognitive styles and attitude toward computers. Journal of Educational Technologyand Society, 9(1), 289.

Aprilianti, E. (2014). Hubungan Gaya Kognitif dengan Hasil Belajar Fisika Siswa Kelas X SMA Negeri Se-Kecamatan Kota Baru Jambi. Artikel Ilmiah, 1-10.

Khodadady, E., \& Tafaghodi, A. (2013). Cognitive styles and fluid intelligence: Are they related?. Journal of Studies in Social Sciences, 3(2), 138-150.

Noto, M. S., Hartono, W., \& Sundawan, D. (2016). Analysis Of Students Mathematical Representation And Connection On Analytical Geometry Subject. Infinity Journal, 5(2), 99-108.

Razali, M., Jantan, R., \& Hashim, S. (2003). Psikologi pendidikan. PTS Professional.

Sulaiman, S. (2013). Profil Berpikir Geometri Siswa SMP ditinjau dari Perbedaan Gaya Kognitif. Jurnal Ilmiah MITSU, 1(2).

Suprijono, A. (2009). Cooperative learning: teori \& aplikasi PAIKEM. Pustaka Pelajar.

Suryanti, N. (2014). Pengaruh Gaya Kognitif Terhadap Hasil Belajar Akuntansi Keuangan Menengah 1. JINAH (Jurnal Ilmiah Akuntansi dan Humanika), 4(1), 1393-1406.

Ulya, H. (2015). Hubungan Gaya Kognitif dengan Kemampuan Pemecahan Masalah Matematika Siswa. Jurnal Konseling GUSJIGANG, 1(2).

Witkin, H. A., Moore, C. A., Goodenough, D. R., \& Cox, P. W. (1977). Field-dependent and field-independent cognitive styles and their educational implications. Review of educational research, 47(1), 1-64. 